\title{
DJ LU: Street Art
}

\author{
George Rivera, Ph.D* \\ Professor Department of Art \& Art History University of Colorado Boulder, Colorado (USA)
}

*Corresponding Author: George Rivera, Ph.D., Professor Department of Art \& Art History University of Colorado Boulder, Colorado (USA)

\begin{abstract}
Street artists in Latin America are addressing global issues well beyond the local. Their work is found on streets throughout urban areas. Dj Lu, a street artist in Colombia, uses "pictograms" to confront pedestrians with stenciled images of war and global warming. Semiotics is used to analyze DJ Lu's signs that appear on the streets of Bogota.
\end{abstract}

Key words: Dj Lu, Street art, Semiotics, Colombia

Street artists seek to communicate with the general public so that their visual images are understood. It is unlike most graffiti art, which is encoded and understood by a select community of other graffiti artists. Street art seeks to make a statement about some issue, e.g., globalization, war, global warming, oppression, etc. Street art begs to be decoded so that a particular visual representation conveys meaning related to society. It is often produced by those educated in art schools and has a theoretical base in art. ${ }^{1}$

Long before street art emerged, graffiti art dominated the public sphere. Grafitti artists in New York City were active in putting their pop art images on subway trains. ${ }^{2}$ This spread to other spaces like public walls and other street locales. It continues to this day. The street art tradition gained popularity with the work of Keith Haring ${ }^{3}$ and Bansky. ${ }^{4}$ Their work was stylized with a visual language that was easily recognizable and decipherable.

Today, other issues are being addressed. Street artists have become aware of the impact of globalization. ${ }^{5}$ They have become interested in issues that transcend those found in any one particular country. They are addressing issues that their country has in common with other countries. Thus, they are creating street art that focuses on the following themes (among others): war and environmental issues.

$\mathrm{Dj} \mathrm{Lu}$ is one of this new generation of artists. He is a street artist who primarily works in Bogota, Colombia though some of his work can be found in cities throughout the world. He is part of a very strong graffiti/street art movement in Bogota. ${ }^{6}$ Moreover, he is part of movement that is evident throughout Central and South America. ${ }^{7}$ A lot of the artists in Bogota are graffiti artists, but a growing number of street artists are emerging. Most of the artists began by commenting on their country's government, especially dictatorships and other oppressive realities.

$\mathrm{Dj} \mathrm{Lu}$ works in the stencil tradition, whether these be large mural-like works on the sides of buildings or his smaller stencils that must be viewed up close and personal. These smaller works, which he terms "pictograms" that are often 10 inches by 9 inches, can only be seen when one is walking the streets of Bogota. You will find these other smaller works on street signs, street walls, street lights, and in all places that require the passerby to notice. $\mathrm{Dj}$ Lu makes these street messages available to those who glance at their urban environment and are thereby captured by the simplicity of the message, and its profundity, all at the same time.

To fully understand the street art of $\mathrm{Dj} \mathrm{Lu}$, we must look at its theoretical roots in contemporary art. One way to approach his work is to analyze it using semiotics. What this artists presents are signs. His images take signifiers and uploads another signifier unto it that transfers the meaning of what was originally signified. In semiotic terms, it takes iconic signifiers and subverts their meaning. ${ }^{8}$ Goffman, 
a dramaturgical sociologist, would view $\mathrm{Dj}$ Lu's works from a theoretical viewpoint called Frame Analysis. ${ }^{9}$ Goffman would view $\mathrm{Dj}$ Lu's work as merging two frames. What results is a new frame recognizable from the first frame but with an added frame superimposed upon it creating an entirely new frame. This is what $\mathrm{Dj}$ Lu does best in his street art.

Colombia has suffered for over fifty years in a civil war that does not seem to cease. Therefore, Dj Lu has several works that address war and conflict throughout the streets of Bogota.

The dangers of war, and what precipitates it are evident in Pictogram 1 and Pictogram 2. Herein he illustrates war as supported by a war economy and that it is a chance game that no one can win.

Pictogram1: Slot Machine $\quad$ Pictogram2: War Economy (No One Wins)

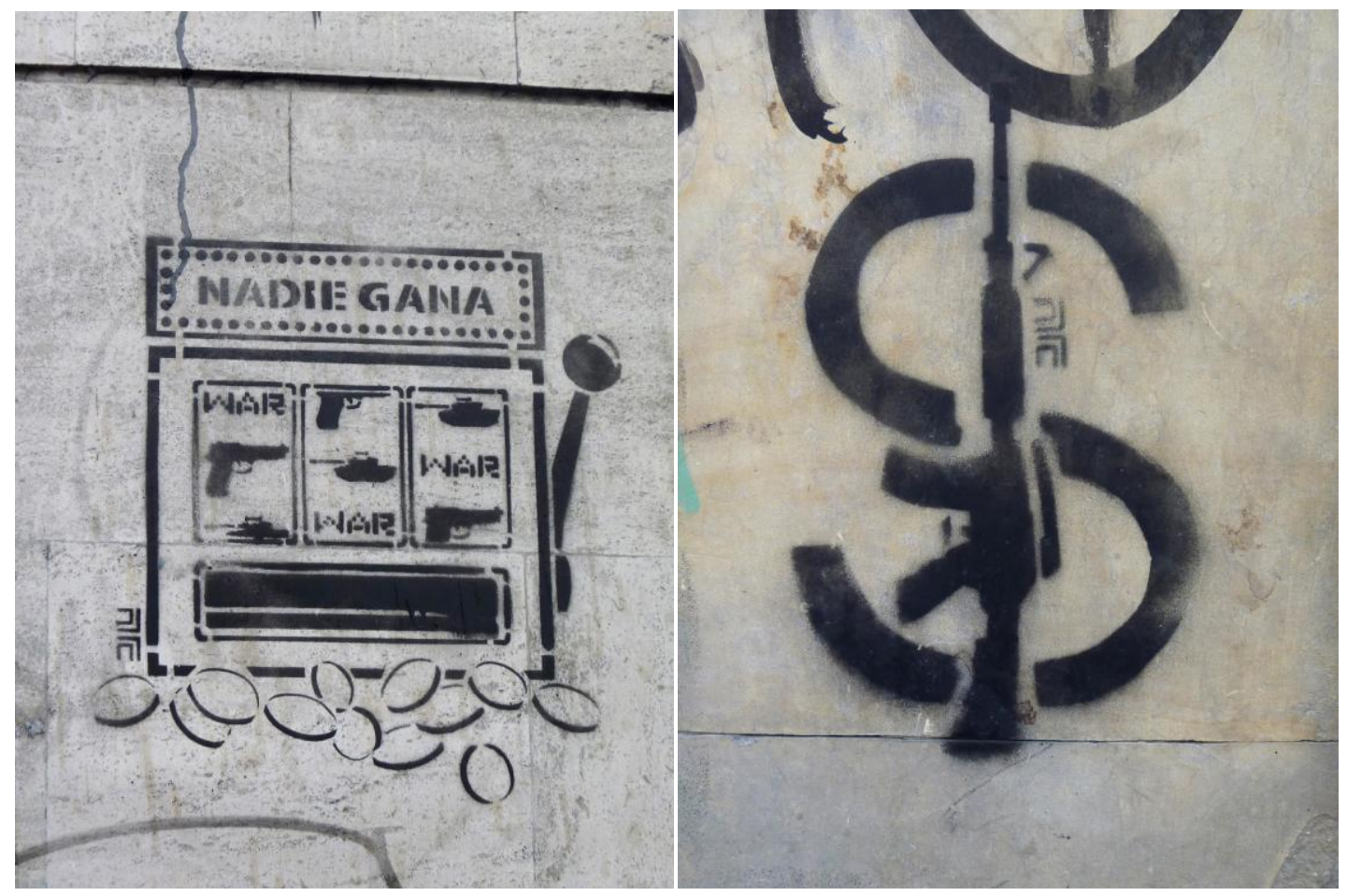

In Pictogram 3 and Pictogram 4, Dj Lu depicts the war bugs with weapons as wings of insects that bite and are a constant nuisance to human beings.

Pictogram3: Mosquito

Pictogram4: Wasp

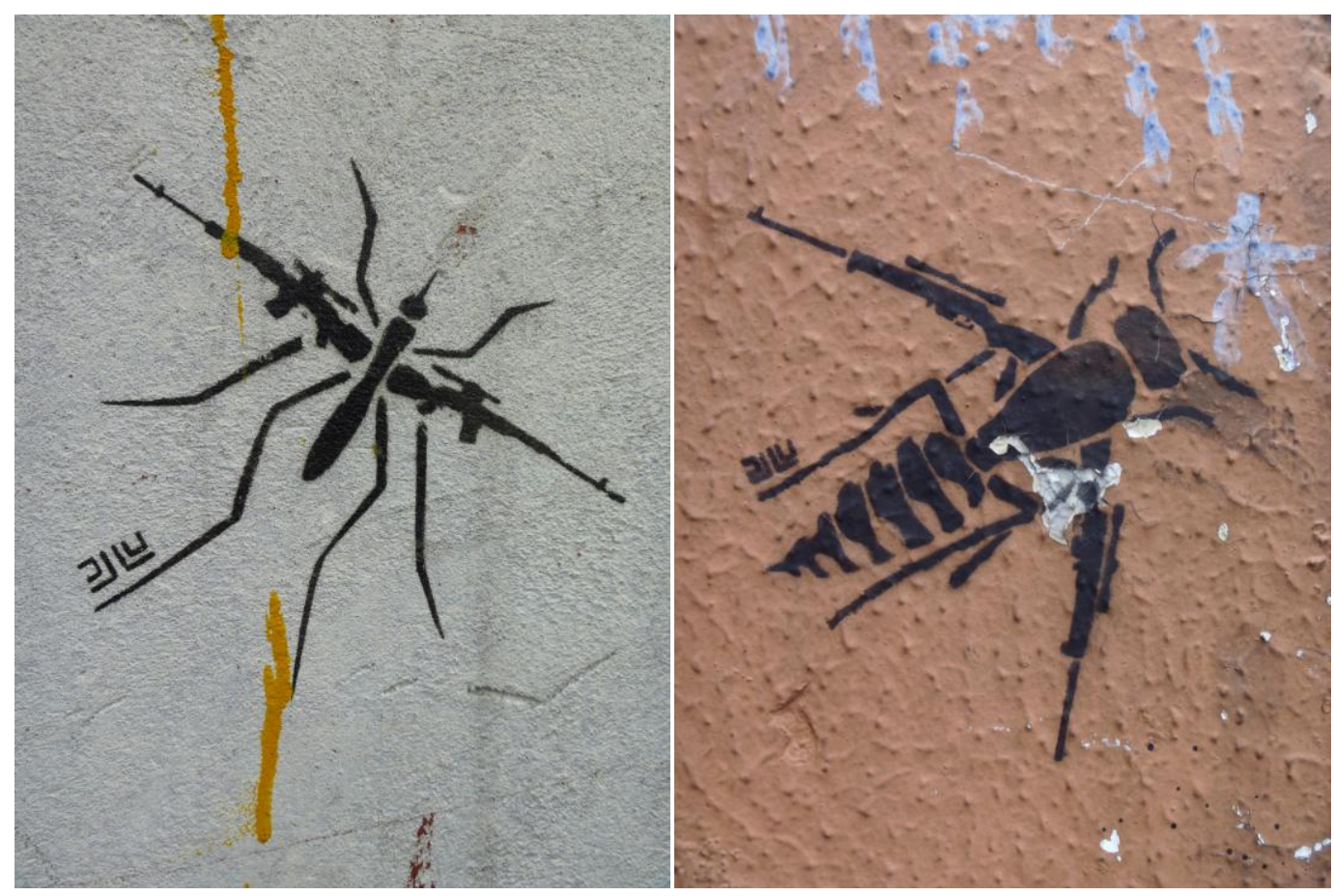


$\mathrm{Dj} \mathrm{Lu}$ also addresses the consequences of war. In Pictogram 5 he characterizes war as guns raining down on innocent people. The aftermath of war is seen in Pictogram 6, which shows a soldier with an amputated leg. Modern medicine allows more soldiers to survive than in other wars, but they are rendered amputees.

Pictogram5: Rain

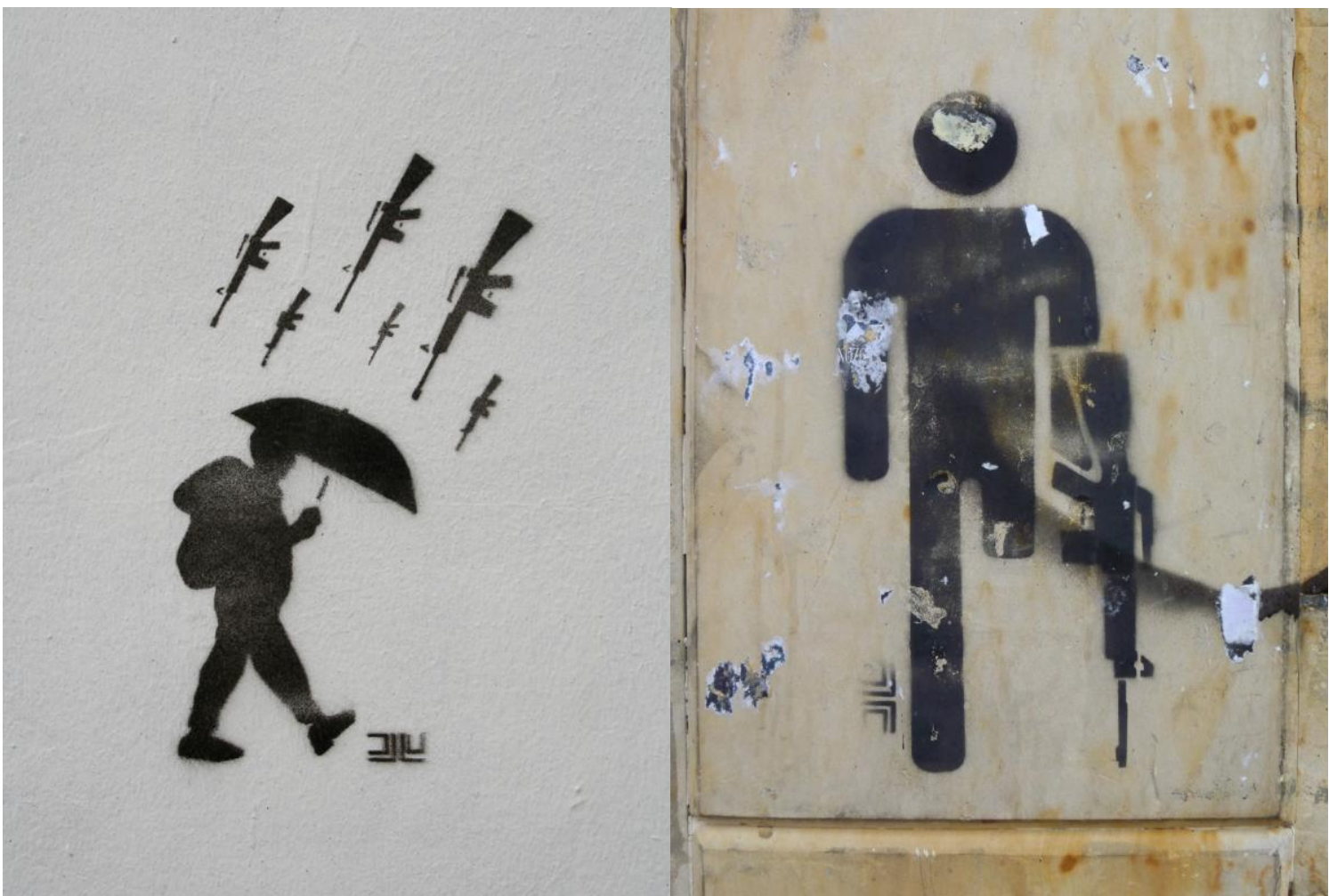

In another area altogether, $\mathrm{Dj} \mathrm{Lu}$ represents environmental concerns that are preoccupying contemporary societies throughout the world. In Pictogram 7, he addresses how pollution from factories is affecting the air that we breathe, as well as the ozone layer. Pictogram 8 illustrates our dependence on oil (fossil fuels) that is bringing death to the population because we are not using other less toxic forms of energy.

\section{Pictogram7: Smoke - Planet $\quad$ Pictogram8: Death - Pump}

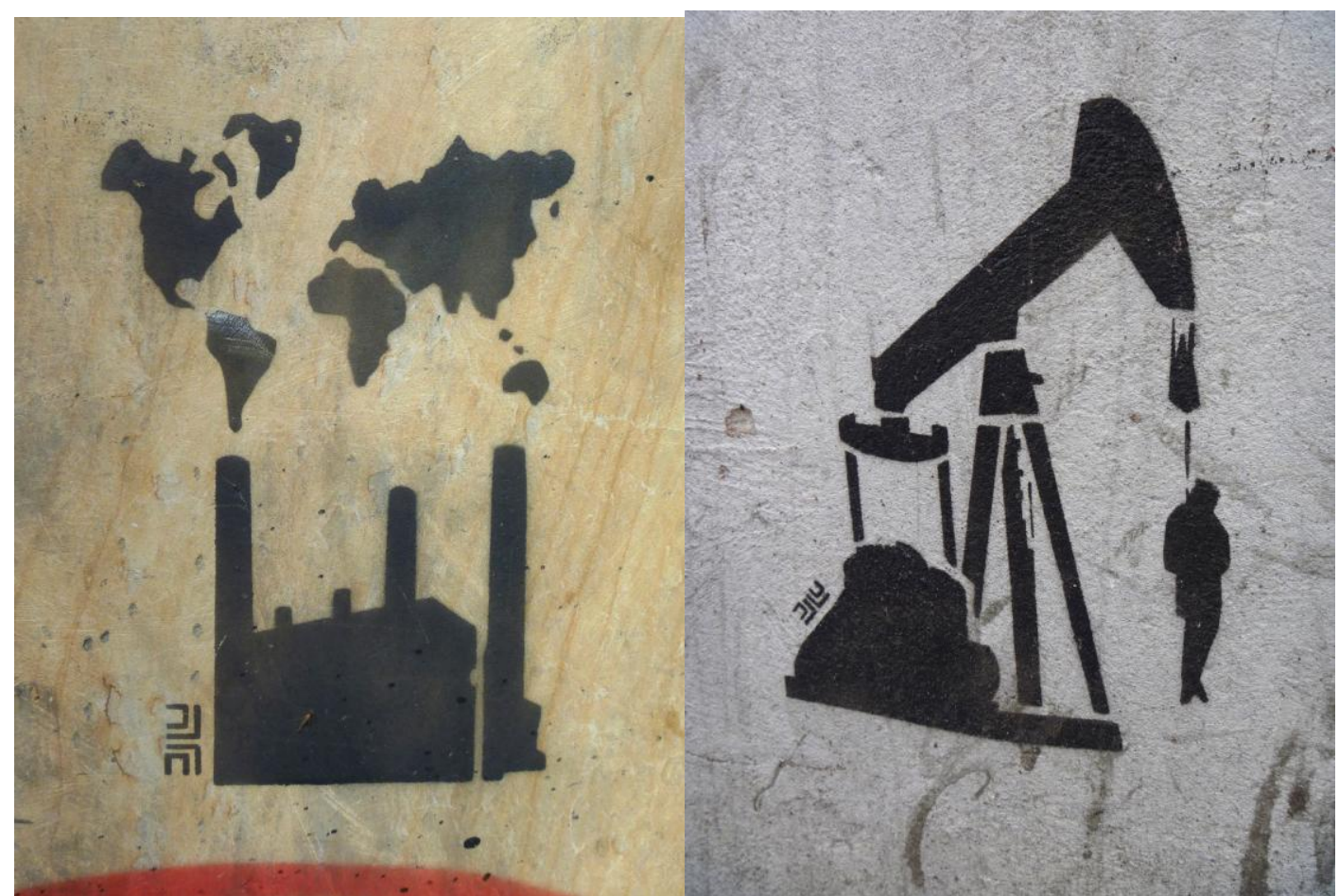


Pictogram 9 portrays the planet earth as a time bomb that is about to explode if we do nothing to protect the earth.

Pictogram9: Planet - Bomb

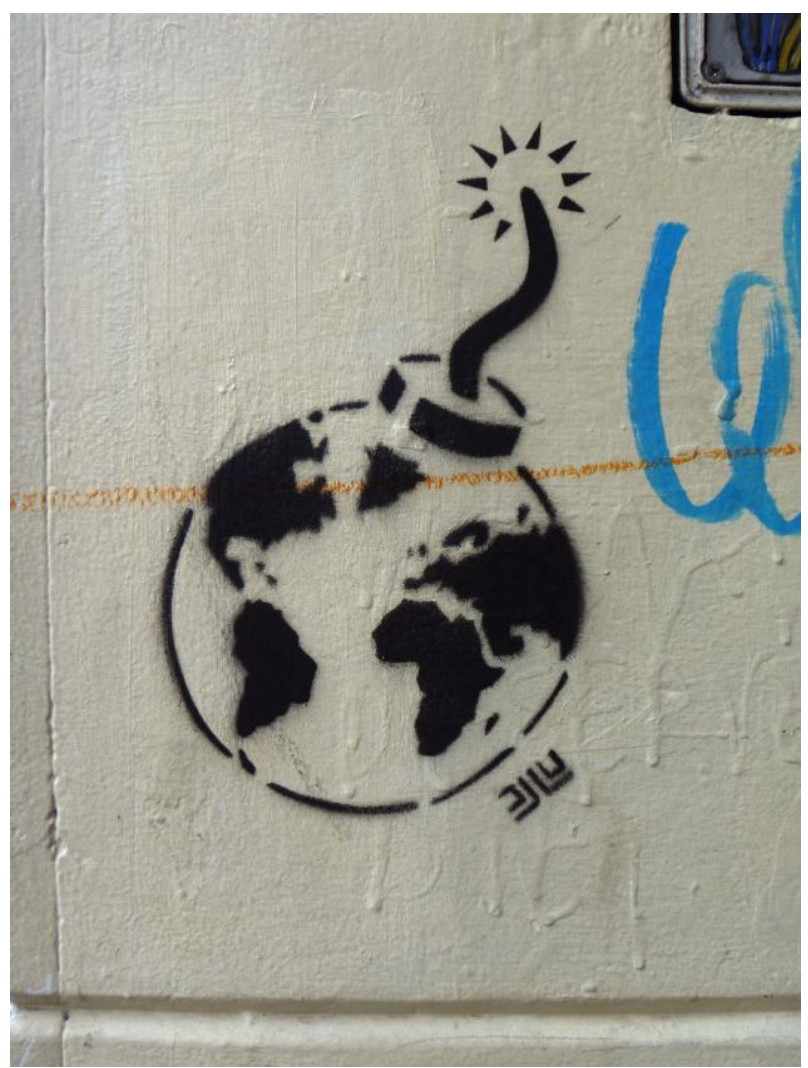

Though many view street art as primarily "graffiti" that is undesirable on city streets, there is some street art that propels us to think about the world that we have created. $\mathrm{Dj} \mathrm{Lu}$ is one of those street artists who address the human condition through signs on city streets so that all who view it might think about the present condition of the world in which we live. His pictograms contain messages of what we must do to save our planet from war and environmental disasters. If we dare to stop and notice the world around us as depicted in $\mathrm{Dj}$ Lu's iconic signifiers, we will see the possibility of another world far greater than that in which we live.

\section{NOTES}

[1] Cedar Lewisohn, Street Art, the Graffiti Revolution (New York: Abrams, 2008).

[2] Roger Gastman and Caleb Neelon, The History of American Graffiti (New York: Harper Collins Publishers, 2011).

[3] Alexandra Kolossa, Keith Haring (Taschen $25^{\text {th }}$ Anniversary Special Edition) (Cologne, Germany: Taschen GmbH, 2009)

[4] N.A., Bansky, Wall and Piece (London: The Random House Group Limited, 2006).

[5] Nicholas Ganz, Graffiti World: Street Art from Five Continents (New York: Abrams, 2009).

[6] N.A, Bogota Street Art (Bogota, Colombia: www.bogotastreetart.com, 2012).

[7] Maximiliano Ruiz, Nuevo Mundo, Latin American Street Art (Germany: Gestalten, 2011).

[8] Daniel Chandler, Semiotics, Second Edition (New York: Routledge, 2007).

[9] Erving Goffman, Frame Analysis: An Essay on the Organization of Experience (Cambridge: Harvard University Press, 1974). 


\section{AUTHOR'S BIOGRAPHIES}

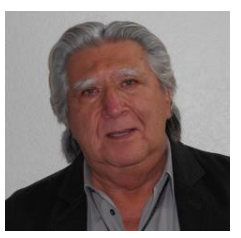

George Rivera, is a sociologist in the Department of Art \& Art History at the University of Colorado in Boulder, Colorado (USA).He is a Fulbright Scholar, and hislife's work is archived at the Benson Library at the University of Texas (USA). Dr. Rivera has publishedarticles in national and international journals and has hadexhibitionsthroughout the world. In addition to beingan art critic, he is an artist and international curator.

Citation: George Rivera, Ph.D. "DJ LU: Street Art" International Journal of Humanities Social Sciences and Education (IJHSSE), vol 7, no. 8, 2020, pp. 18-22. doi: https://doi.org/10.20431/2349-0381.0708003.

Copyright: (C) 2020 Authors. This is an open-access article distributed under the terms of the Creative Commons Attribution License, which permits unrestricted use, distribution, and reproduction in any medium, provided the original author and source are credited. 